Kafkas Üniversitesi Sosyal Bilimler Enstitüsü Dergisi

Kafkas University Journal of the Institute of Social Sciences

Sonbahar Autumn 2019, Ek Sayı Additional Number 2, 207-222

DOI:10.9775/kausbed.2019.027

Gönderim Tarihi: 25.07.2019

Kabul Tarihi: 30.07.2019

AKAN SATAYEV'İN FÍLMLERINDE SOVYET KAZAKISTAN'IN SON YILLARI

\title{
The Last Years of Soviet Kazakhstan in Akan Satayev's Films
}

Lokman ZOR

Dr. Öğr. Üyesi, Niğde Ömer Halisdemir Üniversitesi

İletişim Fakültesi

lokman_zor@hotmail.com

ORCID ID: 0000-0001-5352-1254

Çalışmanın Türü: Derleme

$\ddot{\boldsymbol{O}} z$

Akan Satayev, son dönem Kazakistan sinemasının en üretken yönetmenlerinden biridir. Televizyon Yönetmenliği alanında tamamladı̆̆ y ÿ̈ksekögreniminden ve farklı televizyon yapımlarındaki uzun süreli iş tecrübesinden sonra Sataifilm adıyla 2003 yllında kurduğu kendine ait film yapım şirketi aracıllğılyla 300 civarında reklam filmi ve televizyona yönelik çok sayıda yapım üretmiştir. Sinemaya yönelik özel ilgisi sonucunda, yapımcı ve yönetmen olarak sinemaya yönelen Satayev, yönetmenliğini yaptığ ilk uzun metraj filmini 2007 yllında çekmiştir. Bu tarihten sonra Kazakistan sinema tarihinde iz birakacak filmlere de imza atan Akan Satayev, her biri farklı başarılar elde eden ve Kazakistan sinema seyircisi tarafindan beğeni gören 10 uzun metraj film daha yönetmiştir.

Bu çalışma, Akan Satayev'in, konusu Sovyetler Birliği döneminde geçen filmlerinde Sovyetler Birliği'nin son yıllarının anlatımını ideolojik söylem bakımından ele almaktadır. Betimsel bir araştırma olup genel tarama modeliyle hazırlanan çalışmanın sinırlılığını Satayev'in Sovyetler Birliği'nin son yıllarında geçen olaylart işlediği, "Racketeer / Haraççı" ve "Districts / Bölgeler" isimli filmleri oluşturmaktadir. Inceleme sonucunda elde edilen veriler Van Dijk'ın eleştirel söylem çözümlemesi yöntemiyle incelenmiş, filmlerdeki söylemin ve bu söyleme ait ideolojik arka planın ortaya konulması hedeflenmiştir.

Anahtar Kelimeler: Akan Satayev, Kazakistan Sineması, Haraççı, Bölgeler, Glasnost ve Perestroyka.

Abstract

Akan Satayev is one of the most prolific directors of the Kazakh cinema in recent years. After he completed his higher education in Television Directing and gained long years of work experience in diverse television productions, he founded in 2003 his own production company Sataifilm, through which he produced about 300 commercials and many TV productions. As a result of his particular interest in cinema, Satayev turned to cinema as a producer and director, and shot his first feature film, which was also directed by him, in 2007. Shooting films that would make a mark in the Kazakh cinema since then, Akan Satayev directed 10 more feature films, each of which has gained particular success and been appreciated by the Kazakh cinema audience.

This study analyzes Akan Satayev's description of the final years of the Soviet Union in his films set during the Soviet era in terms of ideological discourse. It is a descriptive study conducted through general survey model, and the scope of the study consists of Satayev's films "Racketeer" and "District" in which he tells the events occurring in the final years of the Soviet Union. The data obtained from the study was analyzed by using Van Dijk's critical discourse analysis method, and it was aimed to demonstrate the discourse in the 
films as well as ideological background of this discourse.

Keywords: Akan Satayev, Kazakhstan Cinema, Racketeer, District, Glasnost and Perestroika.

\section{GíRiş}

Bağımsızlık sonrası Kazakistan sinemasını yönetmenler bakımından 4 farklı grupta ele almak mümkündür: Birinci grup; çoğunluğu Solovyev'in öğrencilerinden oluşan ve Kazak Yeni Dalgasını başlatan ya da onlarla aynı dönemde ürünler veren yönetmenlerdir. Bu yönetmenler bağımsızlık öncesi filmlerinde ele aldıkları konularla bağımsızlığın adım adım yaklaşmakta olduğunu ifade etmişler, bağımsızlı̆̆ın ilk yıllarında Sovyet döneminin eleştirisini yapıp bir yandan da yeni toplumsal yapıyı resmetmişlerdir. Darezhan Omirbaev, Serik Aprimov, Ardak Amirkulov, Satybaldy Narymbetov gibi yönetmenler bu kuşağın temsilcileridir. İkinci grup; filmlerinde çoğunlukla tarihi ve kültürel köklere bağlı kalmak ve yansıtmak suretiyle yeni Kazakistan Cumhuriyeti'nin ve modern Kazak toplumunun tesis edilmesini ele alan Rustem Abdrashev, Akan Satayev, Ermek Tursunov gibi yönetmenlerin yer aldığı “Kayıp Kuşak”tır. Üçüncü grup; Kazak yeni dalgasını başlatan ve temsil eden yönetmenlerin yetiştirdiği Nariman Turebaev, Gulshat Omarova, Erlan Nurmuhambetov gibi genç yönetmenlerin temsil ettiği "Kazak Yeni Yeni Dalgası" diye isimlendirilen gruptur. Son grup ise; Adilkhan Yerzhanov'un başlattığı Partizan (Gerilla) sineması içerisinde yer alan Adilkhan Yerzhanov, Askar Uzabayev, Talgat Bektursinov, Arslan Akubayev gibi genç yönetmenlerden oluşan ve "Bağımsızlık Çocukları" olarak isimlendirilebilecek yönetmen kuşağıdır (Gulnara Abikeyeva, Kişisel Görüşme, 25 Ocak 2016, Almat1-Kazakistan).

"Kayıp Kuşak"1n en üretken ve dikkat çekici yönetmenlerinden biri Akan Satayev'dir. Tiyatro sanatçısı bir anne babanın çocuğu olarak Kazakistan'1n Karağandı (Karaganda) şehrinde, 23 Aralık 1971'de doğan Satayev, 1988 yılında liseden mezun olduktan sonra bir süre Karaganda yerel televizyonunda yönetmen yardımcısı olarak çalışmıştır. Yüksek öğrenime başladığı Almatı Tiyatro ve Sanat Enstitüsü'nün Televizyon Yönetmenliği bölümünden 1994 yllında mezun olmuştur. Yüksek öğrenimini tamamladığı tarihten itibaren prodüktör olarak çeşitli yapımlar üreten Satayev, bir yandan da sinemaya duyduğu ilginin bir sonucu olarak yönetmenlik yapmıştır.

Akan Satayev, 2003 yılında Sataifilm adıyla kurduğu kendine ait film yapım şirketi aracılığıyla 300 civarında reklam filmi ve televizyona yönelik çok sayıda yapım üretmenin yanı sıra, yapımcı ve yönetmen olarak Kazakistan sinema tarihinde iz bırakacak filmler de çekmiştir. Yönetmen 
olarak 2007 yılında, senaryosunu Timur Zhaksylykov'un yazdığı, ilk uzun metraj filmi, "Racketeer / Haraççı"yı çekmiştir. 90'ların zorlu yaşam koşullarında, var olma mücadelesi veren Sayan'ın hikâyesinin anlatıldı̆̆ 1 Haraççı, sosyo-ekonomik şartların ulusal şampiyonluk kazanmış başarılı bir boksörü yasadışı bir suçluya dönüştürmesini gözler önüne sermektedir.

Satayev, bu filmden sonra eşi ve çocuğuyla seyahat ederken bozkırda yolunu kaybeden bir adamın başına gelen sıra dışı olayları anlattığı "Strayed / Yolunu Kaybetmiş" isimli filmini 2009 y1lında çekmiştir. Filmin senaryosunu Satayev'in birçok filminde senaristlik yapan Timur Zhaksylykov yazmıştır. Fantastik gerilim türündeki film, hem seyircinin hem de sinema dünyasının büyük ilgisini çekmiş, Kazakistan adına en iyi yabancı film Oscar'ına aday olmuştur.

Satayev, 2011 yılında, Hollywood y1ldızı Vinnie Jones'un başrolde oynadığ1 "The Liquidator / Likidatör"ü yönetmiştir. Seyircinin beğenisini kazanan ancak umulduğu boyutta başarı yakalayamayan Likidatör'den sonra kariyerinin zirvesine çıkmasını sağlayan "Myn Bala: Warriors of the Steppe / Binlerce Çocuk: Bozkır'ın Savaşçıları” (2012) isimli filmi çekmiştir. Kazakistan'ın bağımsızlığının 20. yıldönümü anısına çekilen tarihi macera türündeki film, Kazak gençlerinin esaret ve baskıcı anlayışa başkaldırıp mücadele etmesini ele almaktadır. Kazaklarla Çungarlar arasında 1730 yılında yaşanan gerçek olaylar, özellikle Kazak gençlerin özgürlük uğruna verdikleri savaş üzerinden anlatılmıştır. Başarılı savaş sahneleri ile yüksek bütçeli Hollywood yapımı tarihi filmleri aratmayan film, bağımsızlık sonrası Kazakistan'da çekilen en önemli filmlerden biri olarak kabul edilmektedir (Zor, 2016:202).

Üç y1l süren suskunluğun ardından 2015 yılında, ilk filmi Haraççı'nın devamı niteliğindeki aksiyon filmi "Racketeer 2 / Haraççı 2"yi çeken Akan Satayev, 2016 y1lında da İngilizce olarak tamamen yabanc1 oyuncuların rol aldığ "Hacker / Hacker"1 seyircinin beğenisine sunmuştur. Ukraynalı bir göçmen olan Alex'in, sanal ortamda kanun dışı işler yaparak ailesinin geçimini sağlamasını konu alan film, sürükleyici öyküsüne rağmen beklenmeyen vasat bir sonla biter. Senarist ve yapımcı/yönetmenin dışında görev alanların neredeyse tamamının yabancı olmasından dolayı film, Kazakistan seyircisi tarafından beklendiği ölçüde sahiplenilmemiştir.

Satayev, aynı y1l, ciddi boyutta ses getiren filmi, "Road to Mother / Anaya Giden Yol"u da çekmiştir. Çekimleri Kazakistan, Azerbaycan ve Beyaz Rusya'da yapılan ve yaklaşık iki bin kişinin rol aldığı Anaya Giden Yol, 1930'lu yıllarda Kazak halkının maruz kaldığı kıtlık felaketini, 
SSCB'nin halkı Sovyetleştirme politikalarını ve İkinci Dünya Savaşı dönemini bir anne ile çocuğu arasındaki sevgi üzerinden anlatır. Bu film aynı zamanda, Amerikan sinemalarında gösterime giren ilk Kazak filmi olarak Kazakistan sinema tarihine geçmiştir (Gulnara Abikeyeva, Kişisel Görüşme, 13 Ekim 2018, Almat1-Kazakistan).

Akan Satayev, 2016 y1lında senaryosunu yine Timur Zhaksylykov yazdığ 1 "Districts / Bölgeler" isimli filmi çekmiştir. Film, 1980'lerin sonlarında Sovyetler Birliği'nin yıkılmasının eşiğinde acımasız "sokak kurallarına" uyum sağlamak zorunda olan genç Arsen'in yaşamı etrafinda dönmektedir. Film, Barselona'da düzenlenen Asya Film Festivali'nin Panorama bölümünde, 2017 yılında "En İyi Sinematografi" ödülü kazanmıştır.

Kazakistan'ın son y1llardaki en üretken yönetmenlerinden biri olan Akan Satayev, 2017 yılında "Alone / Yalnız" isimli filmini çekmiştir. Sokakları, metro istasyonları, dükkanları, ofisleri ve benzer mekanları tamamen boş olan büyük ve garip bir metropolde küçük kızıyla birlikte yaşayan genç bir kadının yalnızlığını anlatan filmde, şehir yaşamının 1ssızlık ve sessizlikle örülü yalnızlığı gizemli bir dille anlatılmaktadır.

Satayev, bu filmden sonra 2018 y1lında iki film birden çekmiştir: “Businessmen / İşadamları"nda Bağımsız Kazakistan'ın 90'lı yıllarda içine düştüğü ekonomik krizi, üç işadamı arkadaş üzerinden anlatmıştır. Daha önce dördünü Rustem Abdrashev'in, birini Rus yönetmen Sergey Snezhkin'in yönettiği “The Way of a Leader / Liderin Yolu” isimli retro serinin altınc1 filmi olan "The Way of a Leader: Astana / Liderin Yolu: Astana" filmini yönetmiştir. Kazakistan'ın Kurucu Devlet Başkanı Nursultan Nazarbayev'in yaşamını konu alan Liderin Yolu'nun altıncı filmi, "Liderin Yolu: Astana", bağımsızlık sonrasında Kazakistan'ın başkenti Astana'nın* kuruluşunu ve başkentin Almatı'dan Astana'ya taşınması hikâyesini anlatmaktadır.

Kazakistan'ın önemli film festivallerinden biri olan Almatı Film Festivali'nin direktörlüğünü de yürüten Akan Satayev, son olarak Saka Türklerinin efsanevi kadın savaşçısı ve ilk Türk kadın hükümdar Tomris Hatun'u anlatan, 2019 yılı sonlarında tamamlanarak gösterime sunulması planlanan "Tomyris / Tomris" isimli bir film üzerinde çalışmaktadır.

\footnotetext{
* 1830' da Akmolı ismiyle kurulmuş, SSCB döneminde Tselinograd, bağımsızlıktan sonra Akmola, 1998'de de Astana ismi verilmiştir. 23 Mart 2019'da Kazakistan Parlamentosu'nun oybirliğiyle aldığı kararla ismi Nursultan olarak değiştirilmiştir.
} 
Akan Satayev'in filmlerinde Sovyet Kazakistan'ın son y1llarının anlatımını ele alan ve betimsel bir araştırma niteliği taşıyan bu makale, genel tarama modeliyle hazırlanmıştır. Tarama modelleri, geçmişte ya da halen var olan bir durumu, var olduğu biçimiyle betimlemeyi hedefleyen araştırma yaklaşımlarıdır. Araştırmanın konusunu oluşturan olay, kişi yahut nesne, kendi şartları içinde ve olduğu gibi tanımlanmaya çalışılır. Tarama modeli aracılığıyla, doğrudan nesne veya kişinin kendisi incelenebileceği gibi, önceden tutulmuş yazılı belge ve istatistikler, resimler, ses ve görüntü kayıtları gibi çeşitli kayıtlara, eski kalıntılara ve alandaki kaynak kişilere başvurularak elde edilecek dağınık veriler, kişisel gözlemler ile bir sistem içinde bütünleştirilerek yorumlanır (Karasar, 2016:77).

Çalışmada uygulanan genel tarama modeli ise; çok sayıda elemandan oluşan bir evrende, evrenle ilgili genel bir yargıya varmak üzere evrenin tamamı ya da ondan alınacak bir grup örnek veya örneklem üzerinde yapılan tarama düzenlemeleri olarak tanımlanabilir (Karasar, 2016:79). Bu bağlamda, "Akan Satayev'in Filmlerinde Sovyet Kazakistan'in Son Y1lları" başlıklı bu çalışma kapsamında genel tarama modeli uygulanmak suretiyle elde edilen veriler, Teun A. Van Dijk'ın geliştirdiği eleştirel söylem çözümlemesi yöntemiyle incelenmiştir.

Eleştirel söylem çözümlemesi, metin ve konuşmalarla ortaya konulan sosyal güçlerin kötüye kullanılması, egemenlik ve eşitsizliklerin çoğaltılması gibi konuları ele alan ve karşı koyma yollarını araştıran bir analitik söylem araştırma türüdür. Toplumsal eşitsizliğin anlaşılmasını ve ortaya çıkarılmasını sağlaması, buna karşı koymanın önünü açması bakımından son derece önemli bir söylem çözümleme biçimidir (Van Dijk, 2003:352). Medya ürünlerine uygun yapısı dolayısıyla özellikle bu alanda son y1llarda çokça tercih edilmektedir. Çalışmada uygulanan eleştirel söylem çözümlemesiyle, Akan Satayev'in Sovyetler Birliği'nin son yıllarını ele alan "Racketeer / Haraççl" ve "Districts / Bölgeler" isimli filmlerindeki söylemin ve bu söyleme ait ideolojik arka planın ortaya konulması amaçlanmıştır.

\section{HARAÇÇI VE BÖLGELER FILMLERINDE SOVYETLER BİRLİĞİ'NİN SON YILLARI}

Akan Satayev'in yönetmen olarak çektiği 11 uzun metraj sinema filminden 3'ü Sovyetler Birliği döneminde geçen konuları ele almaktadır. Bunlardan biri II. Dünya Savaşı dönemine ait bir konuyu işlerken, diğer ikisi ise Sovyetler Birliği’nin son yıllarında geçen konulara yöneliktir. Söz konusu filmlerden ilki aynı zamanda Satayev'in ilk uzun metraj filmi olan "Racketeer / Haraççı", SSCB'nin dağılmasından hemen önceki Glastnost ve 
Perestroyka sürecinde başlayıp bu sürecin devamı niteliğindeki bağımsızlığın ilk yıllarında yaşanan olayları ve karmaşık toplumsal yapıyı yansıtmaktadır. Filmde bağımsızlık sonrasına yönelik ortaya konulan her şey gerçekte Sovyetler Birliği dönemine aittir. Çünkü yaşananlar Sovyet sisteminin bir sonucudur ve bağımsızlıktan hemen sonra Kazakistan Cumhuriyeti'nin henüz kendine özgü sistem ve kurumlarını oluşturamadığı yılları kapsayan bir toplumsal yapı söz konusudur.

Geçmişin Kazak halkını nasıl etkilediğini ve Sovyet sisteminin Kazak toplumsal yapısını nasıl şekillendirdiğini ele alan 2007 yapımı Haraççı'nın senaryosunu Timur Zhaksylykov yazmış, müziklerini Andrey Lifinskiy, görüntü yönetmenliğini Khasan Kydyraliyev ve Iskander Narımbetov yapmıștır. Filmde Murat Bisembin, Sayat Isembayev, Saken Aminov, Vladimir Vdovichenkov, Almagul Rulas, Bolat Kalymbetov, Asel Sagatova, Aidar Mukhametzhanov, Zhan Baizhanbayev gibi oyuncular rol almıştır. Çoğunlukla amatör oyuncuların rol aldığ film, 800 bin Dolar'lık bir bütçeyle, Almatı'da üç ayda çekilmiştir (Crescente, 2008, parag.12).

Hayali kahraman Sayan Bekkarimov'un biyografik yaşam hikâyesinin anlatıldığı Haraççı'nın filmsel olayı, seyirciye anlatıcı olarak bizzat Sayan'ın ağzından aktarılmaktadır. Hikâye, Almatı'da 1970 yılında bir Sovyet Kazak ailesinin çocuğu olarak dünyaya gelen Sayan'ın doğumundan başlayarak hayatını anlatmasıyla başlar. Babasının ısrarı ve bu yöndeki teşvikiyle 12 yaşında boks öğrenmeye başlayan Sayan, azminin ve emeğinin karşılığını kısa sürede alarak kademeli şekilde şehir, bölge ve ulus şampiyonluğu kazanır. $\mathrm{Bu}$ arada bir yandan da okuluna devam etmektedir. Üniversite giriş sınavlarında başarısız olunca 1988 yılında askere gider. Askerlik sonrasında teknik bir üniversiteye girmeyi başarır. Sovyetler Birliği'nde bir süredir yaşanan siyasi bunalım içinden çıkılmaz bir hal alınca SSCB dağılmış, Kazakistan bağımsızlığını ilan etmiştir. Toplumsal ve ekonomik sorunların artmasına sebep olan bu gelişme sonucunda anne ve babası hem işlerini hem de sosyal statülerini kaybederler. Ailesi, binlerce Kazak aile gibi çok büyük zorluklarla karşı karşıya kalır, babası alkol bağımlısı olurken annesi evin geçimini sağlamak için sokakta kişisel eşyalarını satmak zorunda kalır. Bütün bunlar yaşanırken boksa devam eden Sayan, hoşlandığı kızla yaşadığı bir durumdan dolayı teknik üniversitedeki eğitimini yarıda bırakarak tüccarlardan haraç alan yerel bir suç çetesinin lideri Ruslan'ın kendilerine katılma teklifini kabul eder. Ülkede yaşanan süreç; düzensizliğin, adaletsizliğin, yoksulluğun ve güvensizliğin hâkim olduğu, insanların sadece gayri meşru yollarla var olma mücadelesi verip ayakta hatta hayatta kalabildiği bir süreçtir. Katıldığ çetenin en gözde 
elemanlarından biri olan ve bir suç makinesine dönüşen Sayan, yeni yaşamına kısa sürede uyum sağlamış ve Ruslan'ın öldürülmesinden sonra varisi olarak çetenin başına geçmiştir. Bir yandan işleri devam ettirirken diğer yandan da Ruslan'ın katilini bulup intikamını almaya çalışır. Ne var ki onun da sonu aynı olur ve bir gece vakti sokak ortasında 3 saldırgan tarafindan defalarca bıçaklanır. Sayan, yığılıp kaldığı sokak ortasında hareketli yaşamının son anlarını yaşarken, anlatıcı olarak da biyografisinin son sözlerini söyler: "Bu kadar. Bu benim hayatım. Özel bir şey yok. Tekrar yaşama şansım olsaydl, başka bir yol seçer miydim bilmiyorum. Her neyse, bazı şeyleri değiştirmek için çok geç. Sanırım kasem çok dolmuştu" (Haraçç1, 2007).

Haraççı'da genel olarak, Sayan isimli hayali kahramanın biyografisinin arka planında Sovyetler Birliği'nin son yılları ve Kazakistan Cumhuriyeti'nin ilk yılları anlatılmıştır. Bu doğrultuda Sovyetlerden, Sovyet sonrası Kazakistan'a geçiş ve 90'lı y1llarda yaşanan kaos ortamında insanların var olma ve hayatta kalma adına vermek zorunda olduğu mücadele öykülenmiştir.

Filmin aksiyonu, Sovyetler Birliği'nin son lideri Gorbaçov döneminde başlamaktadır. Çernenko'nun ölümüyle boşalan Komünist Partisi Genel Sekreterliği'ne, 1985 yılında, her anlamda radikal değişimler öne süren Mihail Gorbaçov geçmiştir. Sovyetler Birliği sisteminde köklü ve ciddi bir değişimi ifade eden "Glasnost (Açıklık) ve Perestroyka (Yeniden Yapılanma)" kavramlarını öne süren Gorbaçov, sosyalizmin restorasyonu olarak nitelendirilebilecek yeni bir politik süreç başlatmıştır. Yeniden yapılanma anlamındaki Perestroyka ile Sovyet ekonomik sisteminin uyguladığı merkeziyetçi yapıyı değiştirmeyi ve piyasa ekonomisini oluşturmayı amaçlamış, açıklık anlamına gelen Glasnost'la da bu mekanizmayı oluştururken toplumun da desteğini almayı ve yönetimde şeffaflık sağlamayı hedeflemiştir (Zor, 2019:239).

Gorbaçov'un reformları genel anlamda; insanlara daha fazla özgürlük ve daha fazla hak tanıma, basının üzerindeki baskıyı kaldırma, uluslararası nitelikli silahlanma yarışını bitirme, liberal ekonomiyi sağlama, siyasi mahkûmları serbest bırakma ve alkolizmle mücadele etme gibi konuları kapsamaktadır. Batı ölçütlerinde bir devlet yaratmayı hedefleyen Gorbaçov, bu reformları gerçekleştirebilmek için güçlü bir başkanlık sistemi yaratılması gerektiğine vurgu yapmış Stalin diktası ve kültürünün ortadan kaldırılması, devlet terörünün sonlandırılması, Komünist Parti'nin tekeline son verilip demokrasiye geçişin sağlanması, devlet işlerindeki gizli ve kapalı yönetim anlayışının değişmesi gibi bir takım öneriler ileri sürmüştür 
(Başaran, 2017:64).

Yeterince hazırlık yapılmadan uygulanan bu reformlar, SSCB'ne bağlı tüm cumhuriyetlerde var olan ancak gün yüzüne çıkmamış bazı siyasi, ekonomik ve toplumsal sorunların belirginleşmesine sebep olmuştur. Genel anlamda kapalı ve rekabetten yoksun bir yapıya sahip olan SSCB ekonomisi, yapılan reformlardan sonra dinamizm ve rekabet gücünü tamamen kaybetmiştir. Zamanla ortaya çıkan aşırı istihdam, yeni teknolojilerin geliştirilememesi ya da işsizliğe sebep olacağı endişesiyle teknoloji ithal etmekten kaçınılması, işletme yönetim ve organizasyonundaki başarısızlıklar ekonomik açıdan bariz bir durgunluğa sebep olmuştur. Bütün bunların sonucunda kalitesiz mal üretimi mal stoklarını büyütmüş, dev bir ekonominin merkezî planlamayla yönetilmesi başarısızlık getirmiş ve ekonomide arz-talep dengesizlikleri ortaya çıkmıştır. ABD ile girişilen silahlanma yarışı ekonomik yatırımları olumsuz etkileyerek, özellikle tarım sektöründe ve tüketim malları üretiminde yetersiz kalınmasına sebep olmuştur. Sonuçta, bir zamanlar uzay teknolojisi üreten bir devletin vatandaşları, dünya standartlarında ortalama bir yaşam düzeyinden bile mahrum kalmıştır. Öte yandan sistemi ayakta tutacak kendi insan tipini (Sovyet insanı) yaratmayı hedefleyen Sovyetler Birliği, zamanla bu insan tipinin sistemin temellerini aşındıran zararlı bir unsura dönüştüğü gerçeğiyle karşı karşıya kalmıştır (Özsoy, 2006:164).

Glasnost ve perestroyka politikalariyla Sovyet sisteminin yıpranması, bireylerin yaşamlarını derinlemesine şekillendiren siyasal ve sosyal düzende bir takım temel değişimler yaratmıştır. Ülkenin ekonomik yapısını değiştiren pazar ekonomisinin reformları, yüksek enflasyon, yüksek oranda işsizlik, yaşam standartlarında genel bir düşüşü de beraberinde getirmiştir. Sovyet sisteminin uzun yıllar sonunda tesis ettiği göreceli güvenlik hissi tamamen ortadan kalkmıştır (Canşen, 2011:81). Bu durumdan en belirgin ve derin şekilde toplumun gençleri etkilenmiştir. Yetişkinlere göre geçmişle daha zayıf bağları olan gençler özellikle batıya duydukları özenti sonucunda yeni sistemin koşullarına kısa sürede uyum sağlamış, bunun gerektirdiği yaşam koşullarına sahip olmak adına mücadeleye girişmişlerdir. Ülke şartlarından dolayı çoğu zaman yasal olmayan bu mücadele, özellikle gençlerin suça karışması ve yasadış1 suç örgütlerinin ortaya çıkması sonucunu doğurmuştur.

Sovyetler Birliği'ne bağlı tüm cumhuriyetler de söz konusu olan bu durum doğal olarak Kazakistan için de geçerlilik arz etmiştir. Sosyal, siyasal ve ekonomik yapıda baş gösteren bütün olumsuzluklar ve gençlerin karş1 karşıya kaldığı menfi durumlar sonraki yıllarda çekilen Kazak filmlerinde 
etkin bir şekilde işlenmiştir. $\mathrm{Bu}$ doğrultuda çekilen Haraççı da gerek Sovyetlerin son yıllarında gerekse bağımsızlığın ilk yıllarında Almatı'da yaşanan toplumsal kaosu etkili bir dille anlatmaktadır.

Sayan, filmin hemen başından itibaren anlatıcı olarak yaşananlardan bahsederken sık sık ailesinin ve toplumun yaşam şartlarına, ülkenin siyasi ve ekonomik durumuna da değinmektedir. Yaşadığı olaylar bir anlamda o dönem gençliğinin karşı karşıya kaldığı ve birçoğunun farklı şekilde, farklı boyutlarıyla yaşadığı olaylardır. Gençler arasında alkolizmin kök saldığı, uyuşturucu kullanımının yaygınlaştığı, iyi yaşam şartlarına kavuşmak için her yola başvurmanın normal görüldügüü, batıya ait pahalı ürünlerin revaçta olduğu, ahlaki değerlerin zayıfladığ $\breve{1}$, toplumsal dayanışmanın azaldığı, aile müessesesinin yerle bir olduğu, arkadaşlık ve akraba bağlarının gücünü yitirdiği bir süreç söz konusudur. Gençler de böylesi bir ortamda var olma ve varlıklarını sürdürme zorunluluğuyla karşı karşıya kalmışlardır.

Çocuk yaşta spora başlayan ve boksta Kazakistan ulusal şampiyonluğuna kadar yükselen Sayan, siyasi, toplumsal ve ekonomik şartların değişmesiyle sahip olduğu yeteneği kendine yarar sağlayacak biçimde kullanma yolunu seçmiştir. Bu tercihinde, hoşlandığı kızın arabası olan -ki araba o dönemin SSCB koşullarına göre zenginliğin ve gücün bir göstergesi niteliğindedir- bir başka gençle birlikte olması, her şeyi değiştiren dönüm noktası olmuştur. Başarılı ama hem kendisi hem de ailesi yokluk içinde olan bir boksör olmaktansa, yumruklarıyla para ve güç elde edebileceği yasa dışı bir çete mensubu olmayı yeğlemiştir.

Sayan'ın kendine çizdiği bu yol, Sovyetler Birliği'nin o dönemki şartlarıyla doğrudan ilişkilidir. Çünkü ekonominin kötü yönetimi, mal azlığg ve sosyal kazanımların eşitsiz bir şekilde dağılımı söz konusudur. Sosyal olanakların, hizmetlerin ve malların dağılımında temel ölçüt tamamıyla kişisel ilişkilerdir. Yardımlaşma ve dayanışmanın olmadığı, paranın tüm sosyal ilişkilerde temel rol oynadığı, insani değerlerin serbest piyasa ekonomisinin baskısı altında hızla yok olduğu bir yaşam biçimi hâkimdir. Para, aşırı bireyciliği, aşırı bireysel tüketimi ve insanlar arasındaki yabancılaşma duygusunu arttırırken sosyal ilişkileri de hızla yıpratmışır (Canşen, 2011:82). Böylesi bir ortamda suça karışan ve yasal olmayan yollarla var olmaya çalışan birçok genç gibi Sayan da başının çaresine bakma yoluna gitmiştir. Filmde, sosyal yaşamın büyük bir karışıklık içinde olduğu resmedilmiş, herkesin her an her türlü tehdit ve tehlikeyle karş1 karşıya olduğu yansıtılmıştır. Devlet erkinin mutlu bir azınlık tarafından kişisel çıkarları için kullanılması halkı dayanaksız bırakmıştır. Güvensiz, istikrarsız ve tehlikeli sokaklarda bin bir zorluk içinde yaşamını sürdürmeye 
çalışan insanlar, yasadışı yollarla ve sokak çeteleri aracılığıyla kendi güvenliklerini kendileri sağlamaya çalışmaktadır. Toplum içindeki kadın erkek, genç yaşl1, en küçük esnaftan en büyük iş adamına kadar herkes için aynı düzeyde geçerlilik taşıyan tehdit ve tehlikeler ancak ve yalnız çetelerin devreye girmesiyle bertaraf edilebilmektedir. Çünkü devlet otoritesi ciddi şekilde sarsılmış ve devletin hiç kimseye, hiçbir şekilde, herhangi bir teminat ve hizmet sunma olanağı kalmamıştır.

Sayan da, insanlardan haraç alan ve haraç karşılığında iş dünyası içindeki bazı kişileri başka çetelerden koruyan bir çetenin içerisinde yer almıştır. Onun ve arkadaşlarının yaşadığı olaylar, SSCB'nin dağılmadan önceki birkaç yılının ve bağımsızlık sonrasında genç Kazakistan Cumhuriyeti'nin ilk birkaç yılının profilini net bir şekilde gözler önüne sermektedir. Yasalar halkı koruyamamakta, devletin varlığ 1 ve gücü hissedilmemekte, halkın can ve mal güvenliği ciddi tehditler altında bulunmaktadır.

Filmde Sovyetler Birliği’nin siyasi ve toplumsal yapısı farklı yollarla ve sıkça yansıtılmıştır. Sayan'ın anlatıcı olarak verdiği bilgilerin yanı sıra çeşitli görüntüler aracılığıyla da ülkenin içinde bulunduğu durum gözler önüne serilmiştir. Örneğin, Sovyetler Birliği'nin dağılma sürecinin bir parçası olan Gorbaçov iktidarına yönelik darbe girişimi televizyon haberi olarak gösterilirken, halkın yaşadığı yoksulluk ve gerek gelir gerekse güç dağılımındaki dengesizlik ise sokakların, zenginlerin ve yasadışı grupların içinde bulunduğu çelişkili durumun yansıtılmasıyla ortaya konulmuştur.

Sovyetler Birliği'nin dağılmasından ve Kazakistan Cumhuriyeti'nin kurulmasından sonra hiçbir şeyin değişmediği, Sovyet sisteminin sebep olduğu tüm olumsuzlukların aynen devam ettiğine de vurgu yapılmıştır. Birçok insan gibi Sayan'ın anne babası da işsiz kalmış babası alkol illetine bulaşmış, annesi ise sokakta kişisel eşyalarını satmak zorunda kalmıştır. İnsanların yaşamlarını idame ettirebilmek için çırpınmak, geçmişte sahip oldukları toplumsal konum ve itibarlarını bir yana bırakarak büyük mücadeleler vermek zorunda oldukları vurgulanmıştır.

Genel bir ifadeyle söylemek gerekirse; filmde, hayali kahraman Sayan'ın yaşamı üzerinden, sosyalist sendromun zararını gören ve bedelini ödeyen insanların yaşadıkları gözler önüne serilmiştir. Geçmişin, bugünkü Kazakistan'1 nasıl biçimlendirdiğini anlama noktasında önemli bir adım niteliği taşıyan Haraççı, yakın geçmişin ya da daha spesifik bir ifadeyle Sovyet sisteminin Kazakistan'1 nasıl etkilediğini ve günümüzdeki manzarasını nasıl şekillendirdiğini yansıtmaktadır (Norris, 2010, parag. 10- 
$11)$.

Akan Satayev, benzer bir temayı, hemen hemen aynı yılları kapsayan bir başka öyküde, yine gençler üzerinden, bu defa da "Districts / Bölgeler" filminde ele almıştır. Yapımcılığını Ernar Kurmashev'le birlikte yaptığı ve 2016 yılında yönettiği filmin senaryosunu Timur Zhaaksylykov yazmış, müziklerini Roman Vishnevsky ve Alim Zairov yapmıştır. Görüntü yönetmenliğini Khasan Kydyraliev'in üstlendiği filmde Sharip Serik, Asel Sagatova, Zhanna Kuanysheva, Zhandos Aibassov, Gulnara Dusmatova gibi oyuncular rol almıştır.

Film, küçük bir ilçeden Almatı'ya taşınan 16 yaşındaki Arsen Abiyev'in yaşadıklarını anlatmaktadır. Glasnost ve Perestroyka döneminin toplumsal yapısını, gençlerin içinde bulunduğu durumu, karşı karşıya oldukları tehdit ve tehlikeleri, Almatı sokaklarının güvensizliğini ve devlet otoritesinin toplumsal yaşamdaki varlığını eleştirel bir yaklaşımla Arsen'in yaşadıkları üzerinden irdelemiştir.

Yatılı bir okulda spor eğitimi alan Arsen, tam bir judo tutkunu olarak yetişmiş, kendini askeri kariyer için hazırlamıştır. Onu bu doğrultuda teşvik eden babasının Afganistan'daki savaşta ölmesi her şeyi değiştirmiştir. Arseni'in de tıpkı babası gibi bir gün savaşta ölebileceğinden endişe eden annesi, onu okuldan alarak Almatı'ya taşınıp yeni bir okula kaydettirmiştir. Almatı'da da judoya devam eden Arsen, yeni okulunun ilk günlerinde buradaki gençlerin geldiği bölgedekilerden çok farklı olduğunu fark eder: Gençler arasında çeteler, sokak kavgaları, kızlı erkekli eğlenceler, alkol ve sigara kullanımı, başına buyruk hareket etme özgürlüğü (!) ve bunlara benzer durumlar son derece yaygındır. Yeni okulunda kısa sürede Habib ve Azamat adında iki arkadaş edinen Arsen, onların sayesinde metropol hayatının inceliklerini tanımaya ve yaşamaya başlar. Gençler arasında belli bir ağırlık ve prestij vesilesi kabul edildiği için bölgedeki çetelerden birinin üyesi olan Habib ve Azamat aracılığıyla Arsen de çeteye katılır. Ancak ilk başlarda tamamen masum, sıradan, eğlenceli ve itibarlı görünen bu durum zamanla değişmeye ve Onu suçun içine çekmeye başlar. Önceleri sadece bölgenin onurunu savunmaya yönelik kavgalara katılan Arsen, zaman geçtikçe işi küçük suçlar işlemeye kadar götürür. Çeteci gençler arasında belirli bir saygınlığa sahip, korkulan bir çete mensubunun kardeşi olması dolayısıyla bölgedeki en ulaşılmaz kızlardan biri olan Dina ile tanışıp yakınlaşmasından sonra Arsen'in hayatı değişmeye başlar. Kendisi düzenli bir sigara ve alkol tüketicisi değilken çevresindeki gençlerin birçoğunun sigara, alkol hatta esrar ve morfin kullanması, arkadaşı Azamat'ın ölümü, annesinin özellikle çevresinden ve yaşadıklarından dolayı sürekli uyarıp durması, Dina'nın 
çeteci gençlerden ve yasadışı işlerden uzak durmasını istemesi Arsen'in yaşamını sorgulamasına sebep olur. Yaşamında insani, ahlaki, doğru ve yasal olanla bütün bu değerlerin karşıtları Arsen'i içinden çıkılmaz bir çelişkiye sürüklemiş, bir karar verme zorunluluğuyla karşı karşıya bırakmıştır. Ne var ki, her şey için artık çok geçtir, bu süreç onu bir katile dönüştürmüştür.

Haraççı'da gençlerin yaşadığı ve istemeden de olsa içine sürüklendiği olumsuz durumların ya da karşı karşıya olduğu tehdit ve tehlikelerin tamamının sistemden kaynaklandığını, toplumsal yaşamda bu doğrultuda söz konusu olan tüm kötü şeylere Sovyet iktidarının sebep olduğu yansitılırken, Bölgeler filminde gençlerin yaşadıklarının daha çok kendi tercihleriyle ilişkili olduğu ortaya konulmuştur. Haraççı'da Sayan, çökmeye yüz tutan çürümüş Sovyet sisteminin ve kötü bir idare sergileyen, her anlamda başarısız SSCB iktidarının sebep olduğu kötü hayat koşullarından dolayı yasadışı bir yaşamın içine sürüklenmiştir. Oysa Bölgeler'deki Arsen, önünde başka seçenekler bulunmasına rağmen daha çok prestij ve ayrıcalık beklentisiyle yasa dışı bir yaşamı tercih etmiştir. Bu yönüyle Satayev, aynı dönemi benzer hikâyelerle gençler üzerinden farklı iki yaklaşımla anlatmış gibi görünse de iki filmde de sorunun merkezine Sovyet sistemini yerleştirmiştir. Şöyle ki, Bölgeler'de Arsen ve diğer gençlerin önünde yasadışı bir yaşam seçeneğinin bulunmasını bile başlı başına bir sorun olarak yansıtmış, bu durumu eleştirel bir biçimde ele almıştır. Çünkü ideal devlet, tabiiyeti altındaki her ferdin can ve mal güvenliğini sağlamak, geleceğini güvence altına almak ve bütün bunları yasal bir zemine oturtmak zorundadır. Ortada kaos ve yasadışı bir yaşam söz konusuysa bununla ilgili öncelikli sorumluluk devlete aittir. Satayev de, filmde toplumsal yapıyı yansıtmak suretiyle devletin bu anlamdaki yetersizliğini ortaya koyarak, eleştirel bir tutum sergilemiştir.

Filmin ele aldığı dönemin Sovyetler Birliği, bir devlet olarak toplumsal yaşamda varlığını gerçek anlamda ve yeterince hissettiremeyecek kadar ciddi sorunlarla karşı karşıya kalmıştır. Sosyal olanakların kısıtlanması, işsizliğin artması ve maaşların kronikleşmiş bir şekilde ödenmemesi nedeniyle halkın yaşam standartları ciddi boyutta kötüleşmiştir. Yoksullar, her geçen gün daha yoksullaşıp güçsüzleşmiş, kendilerine ihanet ettiğine inandıkları devletten nefret etmeye başlamış, yoksulluktan kurtulmak için ne gerekiyorsa yapmaya hazır bir duruma gelmişlerdir. Doğal olarak bu durum da toplumda suç işleme oranının yükselmesine sebep olmuş, resmi istatistiklere göre suç oranı oldukça hızlı bir yükseliş göstermiştir (Canşen, 2011:83). İnsanların devlete yönelik güveni tamamen 
ortadan kalkmış, devlet kurumları rüşvetin yaygınlaşması ve kişisel ilişkilerin ön plana çıkmasından kaynaklanan sebeplerle işlevini eşit bir şekilde yerine getiremez olmuştur. Devlet otoritesinin sarsılması, etkisini en fazla gençler üzerinde göstermiştir.

Glasnost ve Perestroyka politikaları, zaman içerisinde gangstere dönüşen bir gençlik kültürü yaratmıştır. Pahalı batı mallarını elde etme ve daha iyi bir yaşam arzusu, kolay yoldan para sahibi olma isteği, işsizlik ve eğitimin işlevsizleşmesi gençleri suç işlemeye kışkırtmıştır. Bunun sonucunda organize suç sektörleşmiş ve özellikle finans, ticaret, sanayi, doğal ve stratejik kaynaklar, gıda ve balıkçılık, alkol üretimi ve ticareti, spor, reklâmcılık, devlet ve kamu yönetimi, yasal kurumlar, ziraat ve hatta gönüllü kuruluşlarda bile etkinleşmiştir. Silahlı gruplar ve özel güvenlik servislerini de kapsayacak şekilde örgütlü suç oluşumunun oranı hızla yükselmiştir (Canşen, 2011:85). Toplumun her kesiminde farklı niteliklerde, büyüklü küçüklü suç örgütleri ortaya çıkmıştır. Bu durum öylesine yaygınlaşıp olağanlaşmıştır ki, devlet otoritesinin boşluğunu zamanla toplum içerisindeki bu organize suç örgütleri doldurmaya başlamıştır. Akan Satayev de bu suç örgütlerinin etkinliğini, Bölgeler filminde gerek diyaloglar gerekse görüntüler aracılığıyla geliştirdiği bir hikâyeyle, toplumsal yapının en dinamik ve en önemli kesimini oluşturan neredeyse çocuk yaştaki kolej öğrencileri üzerinden yansıtıp etkili bir yergi atmosferi yaratmıştır.

Filmde, Sovyetler Birliği dönemine yönelik sıklıkla vurgulanan ayrıntılardan biri de alkol kullanımıdır. Arsen ve arkadaşları birçok sahnede toplu olarak alkollü içki ve sigara kullanırken yansıtılmıştır. Gençlerin birçoğu, yaşları henüz küçük olmasına rağmen parklarda, evlerde, barlarda, sokaklarda, bir arada bulunabildikleri her ortamda sigara ve içki içmekte hatta içlerinden bazıları uyuşturucu madde kullanmaktadır. Alkol bağımlılı̆̆ ve tüketimi, filmsel olayların geçtiği Sovyet döneminin en önemli toplumsal sorunlarından biridir. Öyle ki, Gorbaçov'un yönetimi devraldığı 1985 yılındaki verilere göre, Sovyetler Birliği'nde hasta anlamında alkolik sayısı 4,5 milyon, alkole bağımlı olanların sayısı 20 milyondur. Gorbaçov, alkolizmin önüne geçmek için 1985 yılında anti-alkol kampanyası başlatmış, votka geliri bütçenin büyük bir kalemini teşkil etmesine rağmen votka fiyatlarını iki misline çıkararak tüketimi azaltmayı hedeflemiştir. Ne var ki tüketimin azalması söz konusu olmamış, kaçak votka üretimi ve karaborsa satış yaygınlaşmıştır. Halkın votka almaktan vazgeçmesi, devlete 37 milyar Ruble gelir kaybı doğurmuştur. Ayrıca evlerdeki içki üretimi şeker kıtlığına neden olunca, piyasada şeker kalmadığı için ülkenin şeker ithal etmesi sonucunu ortaya çıkarmıştır. Özellikle devletin votkadan elde ettiği gelirlerin 
azalmasıyla oluşan gelir kaybı, enflasyonu ciddi biçimde körüklemiştir. Bütün bunlardan dolayı da 1989 sonbaharından itibaren anti-alkol kampanyası gevşetilmeye başlanmıştır (Uludağ, 1990:130).

Bölgeler filmi, Sovyetler Birliği'ne yönelik anlatımın dışında sinematografik açıdan ve teknik olarak da bazı farklı özellikler içermektedir. Filmin farklı sekanslarına, Habib'in anlatıcı niteliğinde direkt kameraya bakarak olay, durum ve yaşananlarla ilgili açıklama yaptığı birkaç sahne serpiştirilmiştir. Siyah beyaz çekilen bu sahnelerde, arka plandaki kişi ve nesnelere ait görüntüler dondurulurken, açıklama yapan Habib renkli, hareketli ve sesli olarak görüntülenmiştir. Habib'in söyleyecekleri bittikten sonra sahneyi tamamlayacak şekilde her şey yeniden hareketlendirilmiş, seslendirilmiş ve görüntü siyah beyaz olarak ilerletilip sahne sonlandırılmıştır.

Film, özellikle aksiyona yeterince katkı sağlamayan diyalog ve sahnelerin fazla olması dolayısıyla eleştirilmesine rağmen Kazakistan seyircisinden büyük bir ilgi görmüş, gişede hatırı sayılır bir gelir elde etmiştir (Gulnara Abikeyeva, Kişisel Görüşme, 13 Ekim 2018, Almat1Kazakistan).

\section{SONUÇ}

Yönetmen ve yapımcı olarak çok sayıda ürün veren Akan Satayev, yönettiği 11 uzun metraj filmden ikisi aracılığıyla Sovyetler Birliği’nin son yıllarında yaşanan olayları, toplumsal yapıyı, ekonomiyi ve siyasi durumu yansıtmıştır. Söz konusu dönemde SSCB'nin içinde bulunduğu koşulları, Kazakistan bağlamında ve gençler üzerinden Haraççı ve Bölgeler isimli filmlerle resmeden Satayev, bu filmlerde genel olarak eleştirel bir yaklaşım sergilemeyi tercih etmiştir. Konuları, dönemleri, olayları ve karakterleri hemen hemen aynı olan filmlerde, Sovyet sisteminin çürümüşlüğünden kaynaklanan toplumsal sorunların ve yaşanan olumsuzlukların gençleri nasıl etkilediği ve bunun bağımsız Kazakistan'ın geleceğini nasıl şekillendirdiği üzerinde durmuştur.

Glasnost ve Perestroyka politikalarının yarattığı yeni koşullar, Sovyetler Birliği'ni her anlamda içinden çıkılması zor bir bunalıma itmiş, bu bunalımdan en fazla etkilenen toplumsal kesim ise gençler olmuştur. Haraççı'da gençlerin yaşadığı ve istemeden içine sürüklendiği olumsuz durumların, karşı karşıya olduğu tehdit ve tehlikelerin tamamen Sovyet sisteminden kaynaklandığ 1 yansitılmıştır. Filmde doğrudan ortaya konulan bu bakış açısıyla Sovyetler Birliği'ne yönelik bariz bir eleştiri anlayışı sergilenmiştir. Gerek olayların ilerleyişi, gerek görüntüler ve gerekse 
diyaloglar aracılığıyla Sovyet sisteminin çağın koşul ve ihtiyaçlarına cevap veremez durumda olduğu, Sovyet iktidarının bu anlamdaki yetersizliği vurgulanmıştır.

Bölgeler'de ise gençlerin yaşadığı ve karşı karşıya bulunduğu olumsuz durumlar kendi tercihleriyle ilişkilendirilmiş olmasına karşın önlerinde yasadışı bir yaşam seçeneğinin bulunmasının bile sistemden kaynaklanan önemli bir sorun olduğu ortaya koyulmuştur. Devletin varlığını hissettiremeyecek kadar işlevini yitirmesi, her türlü kurumsal yapının tahrip olması, suç oranlarının artması, organize suçun sektörleşmesi, alkol ve uyuşturucu bağımlılığının artması ve nihayetinde bütün bunlardan en fazla etkilenenlerin gençler olması Sovyet sisteminin iflasının resmidir. $\mathrm{Bu}$ resimde halkın perişan halinin gözler önüne serilmesi dışında toplumun yitip giden geleceği, gençliğin içler acısı durumu da öne çıkarılmıştır.

Akan Satayev, bu iki filmde siyasi, ekonomik, kültürel ve toplumsal sorunlardan oluşan atmosferi resmederek Sovyet sisteminin, SSCB'nin dağılmasından hatta Kazakistan Cumhuriyeti'nin kurulmasından sonra bile insanların yaşamlarını ne derece olumsuz etkilediğini, geleceğin nasıl sorunlu bir zemine tesis edildiğini ortaya koymuştur. Bu yaklaşım, basit bir şekilde soruna işaret etmenin ötesinde, başlı başına bir eleştiri niteliği taşımaktadır. Üstelik bu eleştiriyi yaparken söylemini, didaktik ifade ve mesajlara boğmadan, sloganlara sıkıştırmadan, görüntü ve diyaloglarla ince ince işlediği akıcı bir dil ve etkili bir anlatımla ortaya koymuştur.

\section{KAYNAKLAR}

Abikeyeva, G. (2018) Kişisel görüşme, 13 Ekim 2018, Almatı-Kazakistan.

Abikeyeva, G. (2016) Kişisel görüşme, 25 Ocak 2016, Almat1-Kazakistan.

Başaran, D. (2017). Jeltoksan ayaklanması ve bu ayaklanmanın Kazakistan'ın bağımsızlığındaki rolü. Bölgesel Araştırmalar Dergisi, Cilt 1, Sayı 1, 5788.

Canşen, E. (2011). Sovyetler Birliği'nden Rusya Federasyonu'na doğru değişimin yan etkileri. SD ̈̈ Fen Edebiyat Fakültesi Sosyal Bilimler Dergisi, 24/Aralık, 79-88.

Crescente, J. (2008). Akhan Sataev: Racketeer, Kinokultura Online Journal, http://www.kinokultura.com/2008/22r-racketeer.shtml (Erişim Tarihi 20.04.2019).

Karasar, N. (2016). Bilimsel araştırma yöntemi. Ankara: Nobel Yayın Dağıtım.

Norris, Stephen M. (2010). The Gifts of history: Young Kazakh cinema and the past. Kinokultura Online Journal, Issue 27, http://www.kinokultura.com/ 2010/27-norris.shtml (Erişim Tarihi 24.04.2019)

Özsoy, İ. (2006). Sovyet sisteminin çöküşünden tarihi ve evrensel dersler. Bilig Dergisi, 39/Güz, 163-194. 
Uludağ, İ. ve Serin, V. (1990). SSCB'ndeki Türk cumhuriyetlerinin sosyo-ekonomik analizleri ve Türkiye ile ilişkileri. İstanbul: İstanbul Ticaret Odası Yayınları.

Van Dijk, T. (2003). Critical discourse analysis, (Ed: Deborah Schiffrin, Deborah Tannen, Heidi E. Hamilton), The Handbook of Discourse Analysis içinde. (pp. 352-372). Oxford: Blakwell Publishers.

Zor, L. (2016). Kazakistan sinemasında tarihi konulu filmlerle tarih bilinci oluşturma gayretleri. III. Beynelxalq Türk Dünyası Araşdırmaları Simpoziumu Simpoziumun Materiallarl, Cild 3, 199-206, Bakü: Bak1 Avrasia Üniversiteti Yayınları.

Zor, L. (2019), Glasnost (Açıklık) ve Perestroyka (yeniden yapılanma) dönemi Kazakistan sineması. VI.Beynolxalq Türk Dünyası Araşdırmaları Simpoziumu Simpoziumun Materiallarl, Cild I, 239-244, Bakü: Elm ve Tehsil Yayınları. 